\title{
STRATEGIES FOR TEACHING GIFTED STUDENTS ENGLISH GRAMMAR
}

\author{
Maryna Shemuda \\ State Higher Educational Establishment "Pereiaslav-Khmelnytskyi Hryhorii Skovoroda State \\ Pedagogical University", Ukraine \\ shemuda_marina@ukr.net
}

\begin{abstract}
The article highlights the difficulties teachers face in teaching grammar to the gifted students because the individuals with exceptional gifts, talents and learning potential have needs that require specific attention. It presents the typical characteristics of the gifted students aged 17-19 who study according to the educational and professional programme "Secondary education (English language and literature)". Some strategies for teaching gifted students English Grammar in a natural and flowing way to support them and maximise their learning are proposed by the author. One of such strategies is to ensure a multi-level curriculum in Grammar that is personalised to the gifted students' interests and educational needs. An important point in the process of teaching gifted students English Grammar is to provide various enrichment activities and support their emotional growth. The author also describes the strategy of implementing technology usage in the process of teaching gifted students grammar concepts. One of the author's proposed strategies is teaching gifted students English Grammar interactively and putting some fun into this process. The author also puts an emphasis on the importance of incorporating Grammar in context and encouraging gifted students to self-education while learning English Grammar. Implementing the proposed strategies can promote the creation of psychologically comfortable and creative learning environment to the gifted students in the process of learning Grammar. The author offers a variety of activities for everyday use in the process of teaching gifted students English Grammar, aimed at stimulation of the gifted students' imagination, humour, creativity, etc. Finally, being a teacher of the gifted students means to be ready for a constant and professional development and always concentrate on the learner.
\end{abstract}

Keywords: linguistic abilities; giftedness; gifted students; English Grammar; teaching strategies.

\section{Introduction}

The rapid changes in the world require people to be flexible, to take the initiative and lead when necessary, and to produce something new and useful. There has never been owned such enormous knowledge and capabilities in the history of mankind. Exploring the world around, constantly learning new facts about the unknown and unstudied earlier, people at the same time have started to evaluate their own abilities. That is why the issue of giftedness, development of abilities and intelligence comes first in education and the policies of the leading countries of the world.

The problems that society needs to solve in the 21 st century are connected with the gifted individuals who require much more than IQ in addition to analytical, IQ-like skills, they also require creative, practical, wisdom-based, and ethical skills (Sternber, 2017). Undoubtedly, one of the principal tasks of any educational establishment is the search of the gifted students, their support, ensuring of the individuality's comprehensive development, education and upbringing in order to improve abilities and giftedness.

A challenge for any teacher while teaching Grammar is to meet the needs of each student in a classroom because every individual requires opportunities to learn, grow and be challenged to strive for excellence. Today's teachers are set by a task to simultaneously instruct students with exceptional abilities who learn at different speeds and differ in their capacity to get aware of the complex concepts. And while every individual deserves an appropriate education according to one's needs, gifted students in the classroom are not to be an exception. To find appropriate ways to challenge the gifted students while teaching Grammar in the classroom can be a complicated task.

To start with, in higher education establishments, if not supported, gifted students are at a risk of quickly losing interest in further education due to the lack of sufficient attention from the teaching staff and the lack of a system to provide additional educational services. Gifted students often have some discomfort because of expecting them to perform things at a superior level compared to others. Various stimuli are required, teaching tactics must also differ because students may have a different motivation. Every teacher needs to know how to identify the gifted students, teach them Grammar, and to be familiar with the techniques for creating high levels of intellectual challenge in their classrooms. Teachers in the process of teaching Grammar also need to offer or facilitate an access to opportunities for the gifted students to excel in broader intellectual pursuits, sports or the arts. With careful nurturing and appropriate education, the individuals with exceptional gifts, talents and learning potential have a possibility to make a unique contribution to their communities and the world.

The aim of this study is to define and characterise the strategies for teaching English Grammar to the highly gifted and exceptionally gifted students aged 17-19 who study according to the educational and professional programme "Secondary education (English language and literature)". 


\section{Theoretical fundamentals of teaching gifted students}

Higher educational establishments in the process of their work with the gifted students are firstly trying to recognise the specific academic abilities of gifted students on the initial stage of learning and secondly to develop students' creative thinking. Neither legislative documents nor scientific literature give a universal definition of the concept of giftedness which is a delicate and interesting subject. The ambiguity of the term giftedness indicates the complexity and relevance of the research on this problem. In various sources of information, there are some integrated definitions that try to cover the vast majority of human quality's manifestations such as giftedness. For example, the Columbus Group researchers argue that: "Giftedness is asynchronous development in which advanced cognitive abilities and heightened intensity combine to create inner experiences and awareness that are qualitatively different from the norm. This asynchrony increases with higher intellectual capacity" (Neville, Piechowski, \& Tolan, 2013, p. 130).

Linguistic giftedness is a complex phenomenon, combining the development of high linguistic abilities of a person with sufficient motivation. The composition of linguistic abilities is complex and multileveled. The basic components are memory, perception and intellection which underlie various classifications of these abilities. Some scientists include also such personal qualities as emotionality, openness to interaction, will and responsibility (Liferenko, 2013, p. 41).

According to Sousa (2003), possible characteristics of the linguistically gifted students are:

1. heightened awareness of language ("understand the nature of language", have a particular interest in "rhyme, accent, and intonation", or grammar, interested in other languages, and aware of the "relationship between the sounds and words" in these languages);

2. strong communication skills ("easily gain the attention of an audience", entertain using the "humorous or dramatic components of a situation", produce language showing "a creative flair that is exceptional for their age, often using metaphors and poetry", "succinctly express the ideas");

3. strong leadership ("guide a group to achieve its shared goals, while being sensitive to the participation of others");

4. exceptional talent in reasoning and arguing (able to reason on "abstract and hypothetical levels" (spoken/written), justify their opinions, use questioning to challenge others) (p. 114).

Bailey (1997) uses the term "verbally gifted students" and defines such individuals as those who demonstrate at an early age, complex behaviours in listening, speaking, reading, and writing (p. 43). Scientist presents a list of gifted students' characteristics: fluid, descriptive oral language, early mastery of the phonetic code, an advanced ability to use a linguistic symbol system, active engagement in reading or writing tasks for extended periods of time, ability to express complex ideas (p. 48).

The uniqueness of the gifted renders them particularly vulnerable and requires modifications in parenting, teaching and counselling in order for them to develop optimally (Neville, Piechowski \& Tolan, 2013, p. 130).

In spite of the difficulties in defining verbal (linguistical) giftedness, it is understandable that it is a distinct type of advanced ability, one that can give these students an academic advantage over non-verbally gifted individuals. Thus it is necessary for the teachers to get ready to create high levels of intellectual challenge for the gifted students in their classrooms.

\section{Strategies for teaching gifted students English Grammar}

Teaching gifted students English Grammar requires some strategies to support them and maximise their learning. Thus we suggest to establish the following strategies in the process of teaching gifted students English Grammar:

1. Ensuring a multi-level curriculum in Grammar that is personalised to the gifted students' interests and educational needs;

2. Providing various enrichment activities and supporting emotional growth in the process of teaching gifted students English Grammar;

3. Implementing technology usage in the process of teaching gifted students grammar concepts;

4. Teaching gifted students English Grammar interactively and putting some fun into this process;

5. Incorporating English Grammar in context during the work of gifted students with grammar patterns;

6. Encouraging gifted students to self-education while learning English Grammar.

The education of exceptionally gifted students requires curricular adaptations that are difficult to implement in regular classrooms. Intellectually and academically exceptional students need a demanding and fast-paced curriculum that enables these students to be creative producers, socially adjusted individuals and effective leaders (Sullivan \& Rebhorn, 2002). According to Reis \& Renzulli (2004), curriculum compacting is a formally constructed individualised curriculum that eliminates those parts of the normal curriculum in 
which the learner is competent, making space for more challenging tasks and more productive use of the student's time. Curriculum compacting has been shown to be effective in numerous studies in "serving high ability students in a variety of educational settings" (Reis \& Renzulli, 2004, p. 126).

So a strategy that is needed in the process of teaching gifted students English Grammar is Ensuring a multi-level curriculum in Grammar that is personalised to the gifted students' interests and educational needs. High-ability students need a challenging, multi-level curriculum to match educational strategies with the students' advanced cognitive ability. One of the main reasons for such a curriculum is the creation of the necessary conditions for the gifted students' social and emotional development in the environment of peers and the development of their intellectual abilities at the appropriate level. The teachers' task is to differentiate the curriculum so that to address the differences in rate, depth, and pace of learning.

We advise the multi-level curriculum in Grammar to be a student-centred one. It means that such a curriculum is personalised to the gifted students' interests and educational needs. One of the common characteristics of the gifted is enjoying solving problems, especially with numbers and puzzles, concerning with the social and political issues and injustices (Webb, Gore, Amend \& DeVries, 2007).

For instance, if any student doesn't understand when and where to use the conditional tenses, he or she wouldn't see any point in learning it. So the best approach to introduce any grammar structure is using reallife settings and contexts to get gifted students motivated. Gifted students can also be engaged in the curriculum decision-making process while learning Grammar that gives them an opportunity to learn how to take responsibility for their own learning.

It is necessary to take an advantage of using real-life experiences in the process of teaching gifted students various grammar constructions that can be translated into problem-solving academics. Such situations can be challenging for some of them because of their underdeveloped ability to understand social signals. We recommend sharing upcoming events with the gifted students to make them think of the solutions of using their talents to solve real-world issues. Gifted students realise the world happenings on a personal level. Allowing gifted students to find solutions for the problems they observe at the educational establishment or any community will give them a chance to believe that they can be useful and make a difference. Real life examples of the language in use can be found in advertisements, quotations, public notices, cartoons, newspaper articles, music, etc.

The multi-level curriculum in Grammar that is personalised to the gifted students' interests and educational needs will enable all students including gifted ones in the class to learn about a specific area by creating independent projects based on their own individual interests at their own ability level. Such independent projects have the following advantages: performing on the basis of ability level, encouraging creative and original thinking among gifted students, exploring ways of connecting unrelated issues in different original ways. Teachers should try to maximise gifted students' potential by expecting them to do their best and encourage them to advance as quickly as they can. We believe that following the mentioned strategy of ensuring a multi-level curriculum in Grammar can help to engage the high-level thinkers in the classroom and society.

One of the four research-based Renzulli's (2012) subtheories - the Enrichment Triad Model includes three types of enrichment which "are designed to work in harmony with one another and it is the interaction among the types of enrichment. Type I Enrichment includes general, exploratory activities that expose students to problems, issues, ideas, notions, theories, skills - in sum, possibilities. Type II Enrichment involves both individual and group training in a variety of cognitive, meta-cognitive, methodological, and affective skills. Type III activities are individual and small group investigations of real-world problems" (Renzulli, 2012, p. 155). Taking into account the Enrichment Triad Model, one more strategy - Providing various enrichment activities and supporting emotional growth in the process of teaching gifted students English Grammar - was defined. Enrichment activities are sure to enable gifted students to make a continuous progress and let them move quickly through the required curriculum content and onto the more advanced material. Effective planning using various enrichment activities in the process of teaching gifted students English Grammar is decisive in meeting the needs of gifted students.

Gifted students are known to finish their work in grammar sooner comparing with other students. However, it is not desirable to overload them by giving extra grammar activities of the same type. Various enrichment assignments are to be proposed to the gifted students who finish grammar tasks earlier. It is desirable to allow those students to work on any independent projects or engage them in grammar activities which differ from what they have finished doing. For instance, we advise some enrichment activities if there is a task to read a text and to fill in the gaps with the correct variants. The gifted students can be given a task to think of synonyms to the verbs in the text, to replace phrasal verbs from the text by their more formal equivalents, to pick out metaphors in the text and explain what they stand for, etc. Firstly, gifted students are 
still involved in studying, and secondly, they enlarge their vocabulary, work on their language development by doing various grammar tasks.

Teachers play a central role in establishing a good emotional atmosphere and creating a true learning environment (Arnold \& Fonseca, 2007). Thus gifted students also need to be provided by the appropriate environments to stimulate and address cognitive, physical, emotional, and social needs of gifted students in the curriculum. Supporting emotional growth in the process of teaching gifted students English Grammar means to establish and maintain a warm, individualised and accepting atmosphere for the high-ability students to demonstrate their potential or aptitude to learn and perform, to advance at their own rate of learning, etc.

It is essential for teachers to do everything possible to make students get rid of the psychological clamps: some of them are so afraid of mistakes that they try to use only elementary suggestions, avoid complex constructions, etc. While teaching gifted students English Grammar it is recommended to avoid putting too much emphasis on correcting grammar mistakes which may confuse or puzzle the speaker. Gifted students' minds are processing a lot so while teaching grammar teachers should be patient and give them the time to think. Gifted students often have a need of moving when learning, so getting them out of their seats, letting them pace, jump, flap, bounce or toss the ball while learning Grammar can shake them up. Teachers should also notify gifted students about clear deadlines on grammar projects and assignments because they can create unusually high expectations and never see an end in sight.

Gifted students may not excel in all areas, they may be ahead of other students in some areas and behind in others. Despite the advanced capabilities, gifted learners can face such issues regarding anger, boredom, bullying, delinquency, isolation, depression, peer relations, perfectionism, dropping out of school, stress, frustration, and underachievement. To overcome these difficulties and support emotional growth, teaching gifted students Grammar should incorporate different enrichment activities.

Since education takes place under conditions imposed by a technological society, Bruner (1971) maintains that it is not enough to attempt reform through minor curriculum revisions. The programme that fails to set knowledge within the context of action must be replaced.

One way technology can be used is as an intervention to support struggling students by providing additional study materials (Siegle \& Foster, 2001). Another way to apply technology is to help develop students' critical thinking and problem-solving skills (Clarke-Midura \& Dede, 2010). Hence it is important to set up a strategy of Implementing technology usage in the process of teaching gifted students grammar concepts.

The distinguishing characteristics that many gifted individuals share are obtaining unusually large vocabulary and complex sentence structure for age, advanced comprehension of word nuances, metaphors and abstract ideas (Webb, Gore, Amend \& DeVries, 2007). Therefore in the process of teaching Grammar to gifted students, it is useful to enlarge their vocabulary by using technology tools. For example, while teaching Present Continuous, enter in the window of the computer programme Lingvo I am reading (or any other commonly used verb) and the programme will immediately give several hundred examples containing these words. Thus you will show to the gifted students how time is used Present Continuous in a living speech: in what context, with what dialects etc.

Using other different teaching aids (visual, audio and audio-visual aids) such as: online language training sites, dictionary, thesaurus, etc. can be considered a good way to deal with Grammar teaching, as it involves real-life settings into a classroom environment.

Different websites offer a variety of videos (for instance Advanced level https://www.brainpop.com, http://www.roadtogrammar.com etc.) that can be useful for the gifted students to cope with English Grammar. The advantage of the resource is an easy submission of the material and explanation of the native speakers. Auditory and visual memory are the main assistants in any training. Listening to an English song or watching a video in English, gifted students pay attention to how grammatical constructions are used by the native speakers. The following activities for the gifted students can be assigned: write out some phrases with the articles, prepositions, periodically reread them. Gradually, in memory, the correct variant of using this or that design will be postponed.

Using training applications while teaching gifted students Grammar can be useful. For mobile devices, a large number of applications have been created to help learn English Grammar. Teachers can use them so that not one free minute of a gifted student is lost for nothing. For example, the programme Learn English Grammar for Android or iOs helps to work out grammar and test knowledge without requiring access to the Internet. A useful task for the gifted students is to record their voices into an app or movie application as these records and reviews the audio recording let each show how well their grammar is spoken and presented. 
From the high ability students' viewpoint, ability grouping enables them to compete with other students of similar abilities and this motivates them to try harder. They use other students who perform better as benchmarks to assess their own performance (Kulik and Kulik, 1984). Teachers are to provide opportunities for gifted students to participate in flexible groups that collaborate on meaningful tasks, and respond to questions that support achievement of learning goals. For these reasons, it was found out that a strategy of Teaching gifted students English Grammar interactively and putting some fun into this process is essential for implementing.

In the process of teaching Grammar, teachers should let gifted students choose to work either alone or in a group because not all of them can possess the abilities to be managers. It is desirable to put an emphasis on working together in the classroom. Cross-grade groupings can be used while teaching gifted students grammar, as gifted individuals obtain a desire to organise people/things through various games or complex schemas. Gifted students can be clustered together at a table within the regular classroom and suggested the advanced materials, as well as other resources and modification, to meet their exceptional needs.

Gifted individuals are known to gain interest in experimenting and doing things in a different way, to have a wide range of interests (or an exceeding interest in one area) and highly developed curiosity. Thus why incorporating gifted students' passions and interests by putting some fun into the process of teaching grammar is advisable.

Putting some fun into the grammar lessons may bring some interest to the gifted students. For instance, using celebrity biographies is an excellent way to teach and practice any tense. For instance, while discussing the difference between the present perfect and past simple tenses we advise to look for some biography data about any celebrity gifted students are delighted or write one summarising a celebrity's turning points in life. Another proposed assignment is to read the bio to the students and point out the examples that clearly illustrate the usage of two tenses: "The President of the USA, Donald Trump married Marla Maples, an actress in 1993. But he has been married for a third time to Slovenian model Melania Knauss for 12 years. Celebrity photos can be used in teaching gifted students such a grammar theme as the degrees of comparison of adjectives. Get out the celebrity pictures from the entertainment magazines to use them in teaching comparatives and superlatives: "Katie Holmes is taller than Kylie Minogue"; "David Beckham is more talented than Ricky Martin"; or with the comparative adverbs: "Shakira dances better than Ricky, too" etc.

Non-standard teaching methods in the process of teaching gifted students English Grammar can help to put some fun because of their effectiveness: learning grammar in verse, the rhymed formulations are easily remembered. Using poetry helps gifted students to explore the quality of words including the power of metaphoric language and the subtly and complexity of meaning. The irregular verbs of English can be learned by amusing author's rhymes. We also propose to focus on imagery various alternate forms of research (e.g. a photo essay instead of a formal research paper).

Linguistic abilities are characterised by: "the ability to the accelerated processes of thinking in a foreign language, creativity in choosing the communication methods in a foreign language, sustainable motivation to study a foreign language and the possibility of applying received knowledge in new contexts" (Liferenko, 2013, p. 42). That is why teaching gifted students Grammar is effective while doing it creatively, in context and incorporate grammar into stories, games, and other fun activities.

Context gives a more precise understanding of how to use the grammar and provides accuracy in the studied language both in oral and written skills (Wajnryb, 1990). According to Harmer(1991), "students need to get an idea of how the new language is used by native speakers and the best way of doing this is to present language in context" (p.57). Therefore the strategy of Incorporating English Grammar in context during the work of gifted students with grammar patterns is of great importance.

In such a way students will get acquainted with the various grammar points and get aware of the grammar usage, structure and at the same time have some fun doing it. To observe Grammar in context first or just to hear the Grammar context frequently makes brains think about the meaning before the rule of Grammar phenomena being formally explained. It develops an understanding that's grounded in context, and it also develops the students' critical thinking and comprehension skills.

For example, introducing conditionals to the gifted students can be done by writing a theme on the board with some followed examples: "If we don't make acquaintance with him, I'll get disappointed," and a long explanation: when this or that type of conditionals is used. On the other hand, such a theme can be started by tossing out some sentences for the students to finish: "If Ann gets scholarship this term, she...", "If I don't study Grammar well, I... ". Even if the students have never heard this sentence structure before, most of them will catch the idea and complete the sentences. As a result the other students, after hearing some answers, will understand the given Grammar pattern quickly, too. 
Students can be given a task to identify grammar in context by finding examples of any studying grammar concept from the novels, comic books or articles of their favourite magazines, sites or blogs. For instance, it may be helpful to challenge students to identify examples of taught grammar points from any source of information or to find different grammar structures and patterns there. If any verb tense is studied, it is possible to give a task to underline the verbs in a paragraph, to change the verb tense of the passage being careful to conjugate verbs properly.

The gifted students may be given a task to take letter lessons from famous authors. We suggest choosing an interesting book or article in English and begin to rewrite it using various Grammar patterns. The other possible tasks are: discussing English language news events, having a meeting with an English-speaking person, organising extra-curricular activities etc.

Gifted students have been referred to as independent workers who are self-motivated and self-sufficient (Clark, 1992). Sternberg (1997) also emphasised self-management when he referred to gifted students as good mental self-managers because they are able to combine analytic, synthetic and practical giftedness. These descriptions suggest that a strategy of Encouraging gifted students to self-education while learning English Grammar is to be effective.

Self-education in Grammar for the gifted students is one of the most important components of the educational process, during which knowledge, skills and abilities are formed. It provides assimilation of methods of cognitive activity by the gifted students, causes interest in the creative work and, as a consequence, forms the ability to solve various tasks. For effective self-education of the gifted students, it is necessary to fulfil a number of conditions: formation of students' productive abilities; optimal combination of classroom work and independent one; provision of a gifted student with the necessary methodological and educational literature; control over self-education and measures that lead to its more qualitative implementation.

Self-fulfillment of tasks allows gifted students to form the features of cognitive independence: the ability to think independently, the ability to navigate in a new situation, to find creative approaches to the new problem's solution, to determine the ways of obtaining knowledge, etc. The content of the work that is being performed causes to learn cognitive self-activity. Depending on the educational material, sources of information, teaching methods, the level of gifted students' independence will be formed.

We assume that applying of the proposed strategies can help create an attractive, stimulating and wellmanaged learning environment to the gifted students in the process of learning grammar. Implementing some of these strategies also will benefit not just the gifted students but everyone in the classroom. Although teaching gifted students is demanding and time-consuming to some extent, the results are highly rewarding and inspiring. Finally, being a teacher of the gifted students means to be ready for a constant and professional development and always concentrate on the learner rather than the learning.

\section{Conclusions}

Thus in the process of teaching gifted students English Grammar teachers usually face some difficulties because students with the exceptional gifts have needs and problems that, if not taken into consideration, do not allow them to realise their potential. Gifted students obtain some typical characteristics that can be observed by the teachers while teaching Grammar: heightened awareness of language, strong communication skills, strong leadership, exceptional talent in reasoning and arguing etc. Teachers' task is to differentiate curriculum according to the students' abilities. That's why some strategies for teaching English grammar to the gifted students for their development and support are proposed and analysed.

Gifted students need a challenging curriculum to develop their intellectual abilities at the appropriate level. To create such necessary conditions we suggest applying a strategy of ensuring a multi-level curriculum in Grammar that is personalised to the gifted students' interests and educational needs. To stimulate and address the cognitive, physical, emotional, and social needs of gifted students in the curriculum an important point is to provide various enrichment activities and support emotional growth in the process of teaching gifted students English Grammar. Enrichment activities are sure to enable them to make continuous progress and let them move quickly through the required curriculum content and onto more advanced material. Of particular interest are the strategies of implementing technology usage and teaching gifted students English Grammar interactively. Using teaching aids can be considered a good way to deal with teaching gifted students Grammar, as it involves real life settings in a classroom environment. Teaching grammar through the context will help learners perceive the new grammar structures of the language effectively. We consider encouraging gifted students to self-education while learning English Grammar to be one of the most important components of the educational process. 
We hope that performing of the given strategies will help create an attractive, stimulating and wellmanaged learning environment to the gifted students in the process of learning grammar. Implementing some of these strategies also will benefit not just the gifted students but everyone in the classroom. The author presents some activities for everyday use in the process of teaching gifted students English Grammar. To sum up, although teaching gifted students is demanding and time-consuming to some extent, the results are highly rewarding and inspiring.

Research and practice show that the development of giftedness can be delayed, and sometimes even lost at any stage of learning. Therefore, it is necessary to study the development of gifted personalities' linguistic abilities at all stages of education, to improve the existing strategies of their learning, as well as to study the experience of foreign countries in this issue. The next stage of our research will be experimental confirmation of implementation's effectiveness of the strategies for teaching gifted students English Grammar in the higher educational establishments.

\section{References:}

Arnold, J., \& Fonseca, C. (2007). Affect in teacher talk. In Tomlinson, B. (Ed.), Language Acquisition and Development (pp. 107121). London: Continuum.

Bailey, S. (1997). Acceleration as an option for talented students. In B.A. Knight and S. Bailey (Eds). Parents as lifelong teachers of the gifted (pp. 43-50). Melbourne: Hawker Brownlow Education.

Bruner, J. S. (1971). The relevance of education. New York, NY: W. W. Norton.

Clark, B. (1992). Growing up Gifted: Developing the potential of children at home and at school (4th Edn.). New York: Merrill.

Clarke-Midura, J., \& Dede, C. (2010). Assessment, technology, and change. Journal of Research on Technology in Education, 42, 309-328. https://doi.org/10.1080/15391523.2010.10782553

Harmer, J. (1991). The Practice of English Language Teaching. London: Longman

Hertberg-Davis, H. L., \& Callahan, C. M. (2013). Introduction. In H. L. Hertberg-Davis \& C. M. Callahan (Eds.), Fundamentals of gifted education (pp. 1-10). New York, NY: Routledge.

Kulik, C. C., \& Kulik, 1. A. (1984). Effects of ability grouping on elementary school pupils: A meta-analysis. American Educational Research Journal, 19, 415-428.

Liferenko, D.A. (2013). Lingvisticheskie sposobnosti kak osnova razvitiya lingvisticheskoy odarennosti [Linguistic abilities as a basis for the development of linguistic giftedness]. Karelskiy nauchnyiy zhurnal, 1(2), 40-43.

Neville, Ch. S., Piechowski, M.M., \& Tolan, S.S. (Eds.). (2013). Off the Charts: Asynchrony and the Gifted Child. New York: Royal Fireworks Publishing.

Reis, S. M., \& Renzulli, J. S. (2004). Current research on the social and emotional development of gifted and talented students: Good news and future possibilities. Psychology in the Schools, 41, 119-130. https://doi.org/10.1002/pits.10144

Renzulli, J. S. (2012). Reexamining the role of gifted education and talent development for the 21st century: A four-part theoretical approach. Gifted Child Quarterly, 56, 150-159. https://doi.org/10.1177/0016986212444901

Siegle, D., \& Foster, T. (2001). Laptop computers and multimedia and presentation software: Their effects on student achievement in anatomy and physiology. Journal of Research on Technology in Education, 34, 29-37. https://doi.org/10.26803/ijlter.16.9.1

Sousa, D. A. (2003). How the Gifted Brain Learns. CA: Corwin Press.

Sternber, R. J. (2017). ACCEL: A New Model for Identifying the Gifted. Roeper Review, 39, 152-169. https://doi.org/10.1080/02783193.2017.1318658

Sternberg, R.J. (1997) A triarchic view of giftedness: Theory and practice. In N. Colangelo, and G. Davis, Handbook of Gifted Education (2nd Edn.) (pp. 43-53). Needham Heights, MA: Allyn and Bacon.

Sullivan, S. C. \& Rebhorn L. (2002) PEGS: Appropriate education for exceptionally gifted students. Roeper Review, 24, $221-225$. https://doi.org/10.1080/02783190209554184

Wajnryb, R. (1990). Grammar Dictation. Oxford: Oxford University Press.

Webb, J., Gore, J., Amend, E., \& DeVries, A. (2007). A parent's guide to gifted children. Tuscon, AZ: Great Potential Press. 